\title{
Chryseobacterium wanjuense sp. nov., isolated from greenhouse soil in Korea
}

Correspondence

Soon-Wo Kwon

swkwon@rda.go.kr

\section{Hang-Yeon Weon, ${ }^{1}$ Byung-Yong Kim, ${ }^{2}$ Seung-Hee Yoo, ${ }^{2}$ Soon-Wo Kwon, ${ }^{2}$ Yang-Hee Cho, ${ }^{2}$ Seung-Joo $\mathrm{Go}^{2}$ and Erko Stackebrandt ${ }^{3}$}

\author{
${ }^{1}$ Korean Agricultural Culture Collection (KACC), Microbial Genetics Division, National Institute \\ of Agricultural Biotechnology, Rural Development Administration (RDA), Suwon 441-707, \\ Republic of Korea \\ ${ }^{2}$ Applied Microbiology Division, National Institute of Agricultural Science and Technology, RDA, \\ Suwon 441-707, Republic of Korea \\ ${ }^{3}$ Deutsche Sammlung von Mikroorganismen und Zellkulturen $\mathrm{GmbH}$, Mascheroder Weg 1b, \\ D-38124 Braunschweig, Germany
}

\begin{abstract}
A taxonomic study was performed on strain $R 2 A 10-2^{\top}$, isolated from greenhouse soil cultivated with lettuce (Lactuca sativa L.), collected in Wanju Province, Korea. The bacterial cells were Gram-negative, aerobic, short rods. The growth temperature and $\mathrm{pH}$ were $5-35^{\circ} \mathrm{C}$ and $5 \cdot 0-9 \cdot 0$, respectively. Phylogenetic analysis based on 16S rRNA gene sequences revealed that this isolate had $93 \cdot 3-97 \cdot 7 \%$ similarity to Chryseobacterium species: the highest sequence similarities were to the type strains of Chryseobacterium daecheongense (97.7\%), Chryseobacterium formosense (97.1\%) and Chryseobacterium defluvii (96.9\%). Low levels of DNA-DNA relatedness were found between strain R2A $10-2^{\top}$ and the type strains of these three species $(<28 \%)$. Differences in phenotypic properties were found with respect to Chryseobacterium species with validly published names. The predominant cellular fatty acids were iso-15:0 (40.0\%), iso-17 : $03-\mathrm{OH}(21 \cdot 9 \%)$, iso- $17: 1 \omega 9 c(11 \cdot 7 \%)$ and summed feature 4 (iso-15:0 $2-\mathrm{OH}$ and/or $16: 1 \omega 7 \mathrm{c} / t, 11 \cdot 0 \%)$. Menaquinone MK-6 was detected as the sole respiratory quinone. The $\mathrm{G}+\mathrm{C}$ content of the genomic DNA was $37.8 \mathrm{~mol} \%$. On the basis of the genomic and phenotypic evidence, this isolate represents a novel species of the genus Chryseobacterium, for which the name Chryseobacterium wanjuense sp. nov. is proposed. The type strain is R2A10-2 ${ }^{\top}$ $\left(=\operatorname{KACC} 11468^{\top}=\right.$ DSM $\left.17724^{\top}\right)$.
\end{abstract}

As a result of a thorough study of the genus Flavobacterium, the genus Chryseobacterium was proposed by Vandamme et al. (1994). Recently, Chryseobacterium meningosepticum and Chryseobacterium miricola were transferred to the novel genus Elizabethkingia on the basis of a polyphasic taxonomic approach (Kim et al., 2005b). Hence, 12 species with validly published names are currently classified in the genus Chryseobacterium. The type species is Chryseobacterium gleum. All members of the genus are characterized by the presence of MK-6 as the major respiratory quinone and by the presence of large amounts of iso-15:0, iso- $17: 1 \omega 9 c$ and iso-17:0 3-OH fatty acids.

Strain R2A10-2 ${ }^{\mathrm{T}}$ was isolated from greenhouse soil cultivated with lettuce (Lactuca sativa $\mathrm{L}$.) in the Wanju region of Korea. A diluted soil sample was spread on R2A medium (Difco) at $28^{\circ} \mathrm{C}$. Colonial properties were observed after

The GenBank/EMBL/DDBJ accession number for the 16S rRNA gene sequence of strain R2A10-2 ${ }^{\top}$ is DQ256729.
$48 \mathrm{~h}$ incubation on R2A medium. Phenotypic tests such as Gram staining, catalase and oxidase activities, indole production and hydrolysis of agar, casein, DNA, gelatin and starch were performed according to the methods of Gerhardt et al. (1994). The presence of flexirubin-type pigments was determined by flooding the cell mass (taken from agar plates) with $20 \%(\mathrm{w} / \mathrm{v}) \mathrm{KOH}$ (Bernardet et al., 2002). Hydrolysis of carboxymethylcellulose (Sigma) $(0 \cdot 1 \%)$, alginic acid $(0 \cdot 5 \%, \mathrm{w} / \mathrm{v})$, chitin from crab shells $(1 \%, \mathrm{w} / \mathrm{v})$, pectin $(0.5 \%, \mathrm{w} / \mathrm{v})$ and tyrosine $(0.5 \%, \mathrm{w} / \mathrm{v})$ was tested according to the procedures of Gerhardt et al. (1994). Temperature and salinity tolerances were assessed at $5,10,15,20,25,30,33,35,37$ and $40^{\circ} \mathrm{C}$ and $\mathrm{NaCl}$ concentrations of $0,1,2,3,5$ and $7 \%(w / v)$ in $\mathrm{R} 2 \mathrm{~A}$ agar and broth, respectively. $\mathrm{R} 2 \mathrm{~A}$ broth adjusted to initial $\mathrm{pH}$ values of $4,5,6,7,8,9$ and 10 with citrate/phosphate buffer or Tris/HCl buffer (Breznak \& Costilow, 1994) was used to assess the ability of strains to grow at different $\mathrm{pH}$ values. Enzyme activities were determined by using the API ZYM system (bioMérieux). Additional physiological and 
biochemical tests were performed with the API 20NE, API $50 \mathrm{CH}$ and API ID $32 \mathrm{GN}$ systems (bioMérieux).

The 16S rRNA gene was amplified by using a PCR with two universal primers, as described by Kwon et al. (2003). Sequencing of the amplified 16S rRNA gene and phylogenetic analysis were performed as described by Kwon et al. (2003). Neighbour-joining and maximum-parsimony methods were carried out using MEGA, version 2.1 (Kumar et al., 2001). The resulting trees and topology were evaluated by bootstrap analyses (Felsenstein, 1985) based on 1000 resamplings.

Isoprenoid quinones were extracted and analysed as described by Groth et al. (1996). DNA-DNA hybridization was carried out as described by Seldin \& Dubnau (1985). Probe labelling was conducted by using the non-radioactive DIG High Prime system (Roche); hybridized DNA was visualized using the DIG luminescent detection kit (Roche). DNA-DNA relatedness was quantified by using a densitometer (Bio-Rad). For fatty acid methyl ester analysis, cell mass was harvested from trypticase soy agar (Difco) after cultivation for $24 \mathrm{~h}$ at $28^{\circ} \mathrm{C}$. The fatty acid methyl esters were extracted and prepared according to the standard protocol of the MIDI/Hewlett Packard Microbial Identification System (Sasser, 1990). The G $+C$ content of the DNA was determined according to Mesbah et al. (1989), using a reverse-phase column.

Comparison of the almost complete $16 \mathrm{~S}$ rRNA gene sequence (1462 nt) of strain R2A10-2 $2^{\mathrm{T}}$ with sequences deposited in the public databases showed the organism to be a member of the genus Chryseobacterium. The isolate shared sequence similarities of $97 \cdot 7$ and $96.9 \%$ with Chryseobacterium daecheongense DSM $15235^{\mathrm{T}}$ and Chryseobacterium defluvii DSM $14219^{\mathrm{T}}$, respectively. The organism also showed a high level of $16 \mathrm{~S}$ rRNA gene sequence similarity $(97 \cdot 1 \%)$ with Chryseobacterium formosense KCTC $12435^{\mathrm{T}}$. The type strains of all other Chryseobacterium species showed sequence similarities of less than $96 \%$ with respect to strain R2A10-2 ${ }^{\mathrm{T}}$. On the basis of neighbour-joining and maximum-parsimony analyses, strain $\mathrm{R} 2 \mathrm{~A} 10-2^{\mathrm{T}}$ forms a clade with $C$. daecheongense DSM $15235^{\mathrm{T}}$ and C. defluvii DSM $14219^{\mathrm{T}}$. The intraclade branching, as well as the branching point with a sister clade, was supported by high bootstrap values (see Fig. 1 for the neighbour-joining analysis). Because of the relatively high $16 \mathrm{~S}$ rRNA gene sequence similarity values, DNA-DNA hybridization was carried out between the novel isolate and C. daecheongense DSM $15235^{\mathrm{T}}$, C. defluvii DSM $14219^{\mathrm{T}}$ and C. formosense KCTC $12435^{\mathrm{T}}$. Low levels of DNA-DNA relatedness were found between strain R2A10-2 ${ }^{\mathrm{T}}$ and DSM $15235^{\mathrm{T}}(28 \%)$, DSM $14219^{\mathrm{T}}(38 \%)$ and KCTC $12435^{\mathrm{T}}$ $(16 \%)$, supporting the presence of a novel genospecies.

The phenotypic characteristics of strain $\mathrm{R} 2 \mathrm{~A} 10-2^{\mathrm{T}}$ are indicated in the species description and in Table 1. The predominant cellular fatty acids observed in strain R2A10$2^{\mathrm{T}}$ were iso-15:0 $(40 \cdot 0 \%)$, iso-17:0 $3-\mathrm{OH}(21.9 \%)$,

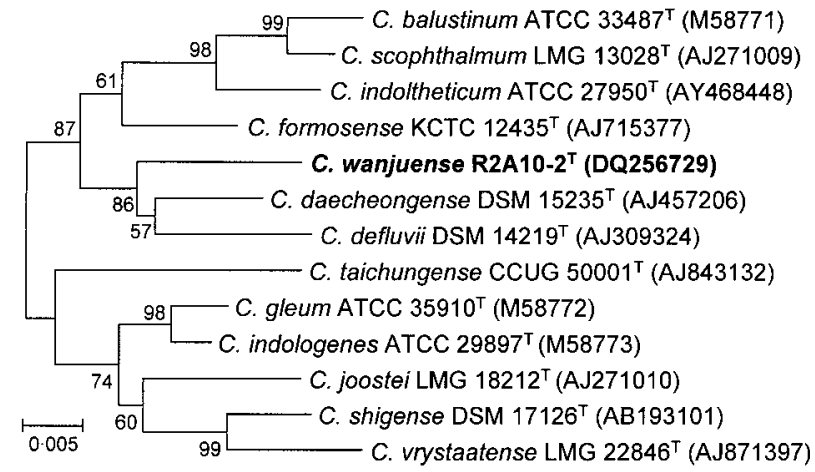

Fig. 1. Unrooted neighbour-joining tree, based on almostcomplete 16S rRNA gene sequences, showing the phylogenetic relationships of strain $\mathrm{R} 2 \mathrm{~A} 10-2^{\top}$ within the genus Chryseobacterium. Bootstrap values $(>50 \%)$ based on 1000 replications are shown at the nodes of the tree. Bar, 0.005 substitutions per nucleotide position.

iso- $17: 1 \omega 9 c(11 \cdot 7 \%)$ and summed feature 4 (iso- $15: 02$ $\mathrm{OH}$ and/or $16: 1 \omega 7 c / t, 11 \cdot 0 \%)$. Table 2 shows the detailed fatty acid composition of strain R2A10-2 ${ }^{\mathrm{T}}$ in comparison with those of all other Chryseobacterium species. Menaquinone MK-6 was detected as the sole respiratory quinone. The $\mathrm{G}+\mathrm{C}$ content of the genomic DNA was $37 \cdot 8 \mathrm{~mol} \%$. Although the phenotypic record is poor for a range of Chryseobacterium type strains, the data available indicate that strain $\mathrm{R} 2 \mathrm{~A} 10-2^{\mathrm{T}}$ differs in terms of several properties, which, in combination, allow its differentiation from other members of the genus Chryseobacterium.

On the basis of the results of DNA-DNA hybridization, phenotypic characterization and 16S rRNA gene sequencing, we propose that strain $\mathrm{R} 2 \mathrm{~A} 10-2^{\mathrm{T}}$ represents a novel species within the genus Chryseobacterium, for which we propose the name Chryseobacterium wanjuense sp. nov.

\section{Description of Chryseobacterium wanjuense sp. nov.}

Chryseobacterium wanjuense (wan.ju.en'se. N.L. neut. adj. wanjuense pertaining to Wanju, a province in Korea).

Cells are Gram-negative rods $(0 \cdot 7-0 \cdot 8 \times 2 \cdot 0-3 \cdot 5 \mu \mathrm{m})$. Yellow colonies with entire edges are formed on R2A agar plates. Grows at $5-37^{\circ} \mathrm{C}$ (optimum $28^{\circ} \mathrm{C}$ ), with $0-2 \% \mathrm{NaCl}$ (optimum $0-1 \% \mathrm{NaCl}$ ) and at $\mathrm{pH}$ 5-9 (optimum $\mathrm{pH}$ 7). Growth occurs on R2A, trypticase soy agar and nutrient agar (Difco), but weak growth is observed on MacConkey agar. Degrades casein, gelatin, starch and tyrosine, and weakly degrades DNA. Urea, chitin and carboxymethylcellulose are not degraded. Utilizes malonate. The type strain shows positive reactions for aesculin and gelatin hydrolysis and for $\beta$-galactosidase activity, but shows negative reactions for nitrate reduction, indole production, glucose fermentation and for arginine dihydrolase and urease activities (API 20NE). Assimilates D-glucose, D-mannose, D-maltose, 
Table 1. Phenotypic comparisons among type strains of Chryseobacterium species

Strains: 1, strain R2A10-2 $2^{\mathrm{T}}$; 2, C. daecheongense DSM $15235^{\mathrm{T}}$; 3, C. defluvii DSM $14219^{\mathrm{T}}$; 4, C. formosense KCTC 12435 ${ }^{\mathrm{T}}$; 5, C. balustinum LMG $8329^{\mathrm{T}}$; 6, C. gleum LMG $8334^{\mathrm{T}}$; 7, C. indologenes LMG $8337^{\mathrm{T}} ; 8$, C. indoltheticum LMG 4025 ${ }^{\mathrm{T}}$; 9, C. joostei LMG 18212 ${ }^{\mathrm{T}}$; 10 , C. scophthalmum LMG $13028^{\mathrm{T}}$; 11, C. shigense DSM $17126^{\mathrm{T}}$; 12, C. taichungense CCUG $50001^{\mathrm{T}}$; 13, C. vrystaatense LMG $22846^{\mathrm{T}}$. Data are from Yabuuchi et al. (1983), Holmes et al. (1984a, b), Mudarris et al. (1994), Vandamme et al. (1994), Hugo et al. (2003), Kämpfer et al. (2003), de Beer et al. (2005), Kim et al. (2005a), Shen et al. (2005), Young et al. (2005) and this study. All strains tested were positive for the presence of flexirubin-type pigments and for the hydrolysis of aesculin, casein and gelatin. +, Positive; W, weak; -, negative; NA, no data available.

\begin{tabular}{|c|c|c|c|c|c|c|c|c|c|c|c|c|c|}
\hline Characteristic & 1 & 2 & 3 & 4 & 5 & 6 & 7 & 8 & 9 & 10 & 11 & 12 & 13 \\
\hline \multicolumn{14}{|l|}{ Growth on/at: } \\
\hline MacConkey agar & $\mathrm{w}$ & - & - & - & + & + & - & + & + & - & - & - & - \\
\hline $37^{\circ} \mathrm{C}$ & + & + & + & - & - & + & + & + & - & - & - & + & - \\
\hline $42^{\circ} \mathrm{C}$ & - & - & + & $\mathrm{NA}$ & - & + & + & - & - & - & - & - & - \\
\hline Indole production & - & - & + & + & + & + & + & + & + & - & + & W & + \\
\hline$\beta$-Galactosidase & + & - & $\mathrm{NA}$ & - & - & + & - & - & - & + & $\mathrm{NA}$ & w & NA \\
\hline Malonate utilization & + & - & - & - & - & - & + & - & - & - & NA & - & NA \\
\hline \multicolumn{14}{|l|}{ Hydrolysis of: } \\
\hline DNA & $\mathrm{W}$ & NA & $\mathrm{NA}$ & $\mathrm{NA}$ & + & + & + & + & + & + & NA & NA & + \\
\hline Glucose & + & - & + & $\mathrm{w}$ & + & + & + & + & + & - & + & w & NA \\
\hline Maltose & - & - & + & - & - & + & + & + & + & - & - & + & NA \\
\hline Trehalose & + & + & + & + & - & + & + & - & + & + & - & + & NA \\
\hline DNA G $+C$ content $(\mathrm{mol} \%)$ & $37 \cdot 8$ & $36 \cdot 6$ & $38 \cdot 8$ & $\mathrm{NA}$ & $34 \cdot 7$ & $37 \cdot 0$ & $37 \cdot 6$ & $33 \cdot 8$ & $36 \cdot 7$ & $34 \cdot 1$ & $36 \cdot 6$ & NA & $37 \cdot 1$ \\
\hline
\end{tabular}

Table 2. Fatty acid composition of strain $\mathrm{R} 2 \mathrm{~A} 10-2^{\top}$ in comparison with other members of the genus Chryseobacterium

Taxa: 1, strain R2A10-2 ${ }^{\mathrm{T}} ; 2$, C. daecheongense $(n=1) ; 3$, C. defluvii $(n=1) ; 4$, C. formosense $(n=1) ; 5$, C. balustinum ( $\left.n=1\right) ; 6$, C. gleum $(n=5) ; 7, C$. indologenes $(n=45) ; 8, C$. indoltheticum $(n=1) ; 9$, C. joostei $(n=11) ; 10$, C. scophthalmum $(n=2) ; 11, C$. taichungense $(n=1)$; 12, C. vrystaatense $(n=7)$. Data are from Hugo et al. (2003), Kämpfer et al. (2003), de Beer et al. (2005), Kim et al. (2005a), Shen et al. (2005), Young et al. (2005) and this study. Values are mean percentages of total fatty acids; fatty acids amounting to less than $2 \%$ of the total fatty acids in all strains were not included. Major fatty acids are in bold. tr, Trace amount (less than $2 \%$ ); - , not detected.

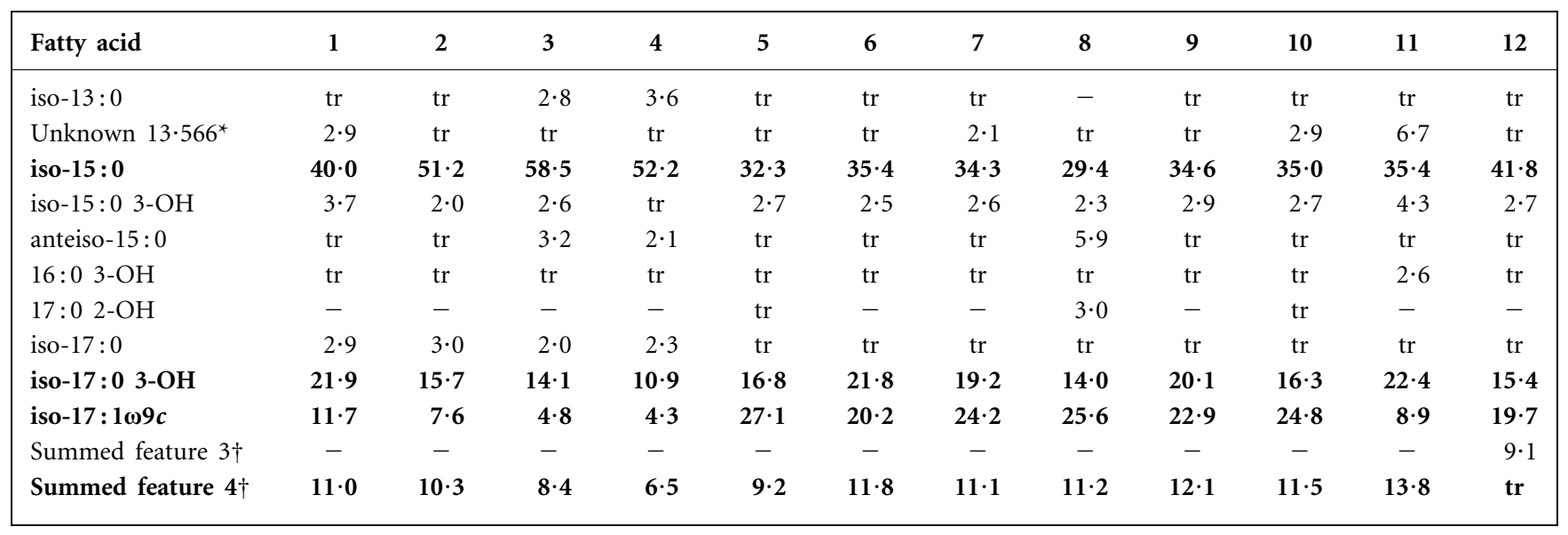

${ }^{*}$ Unknown fatty acid; the number indicates the equivalent chain length.

$\dagger$ Summed feature 3 comprises iso-15:0 2-OH and/or $16: 1 \omega 7 c$ and summed feature 4 comprises iso-15:0 2-OH and/or $16: 1 \omega 7 c / t$. 
sodium acetate, glycogen and L-proline (API 20NE and API ID 32 GN). Does not assimilate L-arabinose, D-mannitol, $\mathrm{N}$-acetylglucosamine, potassium gluconate, capric acid, adipic acid, malic acid, trisodium citrate, phenylacetic acid, L-rhamnose, D-ribose, inositol, D-sucrose, itaconic acid, suberic acid, sodium malonate, lactic acid, L-alanine, potassium 5-ketogluconate, 3-hydroxybenzoic acid, L-serine, salicin, D-melibiose, L-fucose, D-sorbitol, propionic acid, valeric acid, L-histidine, potassium 2-ketogluconate, 3-hydroxybutyric acid or 4-hydroxybenzoic acid (API 20NE and API ID $32 \mathrm{GN}$ ). Activity is observed for alkaline phosphatase, esterase lipase (C8), leucine arylamidase, valine arylamidase, acid phosphatase, naphthol-ASBI-phosphohydrolase and $N$-acetyl- $\beta$-glucosaminidase, weak activity is observed for esterase (C4), cystine arylamidase, $\alpha$-chymotrypsin and $\alpha$-glucosidase and no activity is observed for lipase (C14), trypsin, $\alpha$-galactosidase, $\beta$-galactosidase, $\beta$-glucuronidase, $\beta$-glucosidase, $\alpha$-mannosidase and $\alpha$-fucosidase (API ZYM). Acids are produced only from D-glucose, D-mannose, D-trehalose and gentiobiose (API $50 \mathrm{CH}$ ). The predominant cellular fatty acids are iso- $15: 0$, iso- $17: 03-\mathrm{OH}$, iso- $17: 1 \omega 9 c$ and summed feature 4. Menaquinone MK-6 is the sole respiratory quinone. The $\mathrm{G}+\mathrm{C}$ content of the genomic DNA of the type strain is $37.8 \mathrm{~mol} \%$. The closest phylogenetic relative is $C$. daecheongense.

The type strain, R2A10-2 $2^{\mathrm{T}} \quad\left(=\mathrm{KACC} \quad 11468^{\mathrm{T}}=\mathrm{DSM}\right.$ $\left.17724^{\mathrm{T}}\right)$, was isolated from greenhouse soil cultivated with lettuce ( $L$. sativa L.), collected from Wanju Province, Korea.

\section{References}

Bernardet, J. F., Nakagawa, Y. \& Holmes, B. (2002). Proposed minimal standards for describing new taxa of the family Flavobacteriaceae and emended description of the family. Int J Syst Evol Microbiol 52, 1049-1070.

Breznak, J. A. \& Costilow, R. N. (1994). Physicochemical factors in growth. In Methods for General and Molecular Bacteriology, pp. 137-154. Edited by P. Gerhardt, R. G. E. Murray, W. A. Wood \& N. R. Krieg. Washington, DC: American Society for Microbiology. de Beer, H., Hugo, C. J., Jooste, P. J., Willems, A., Vancanneyt, M., Coenye, T. \& Vandamme, P. A. R. (2005). Chryseobacterium vrystaatense sp. nov., isolated from raw chicken in a chicken-processing plant. Int J Syst Evol Microbiol 55, 2149-2153.

Felsenstein, J. (1985). Confidence limits on phylogenies: an approach using the bootstrap. Evolution 39, 783-791.

Gerhardt, P., Murray, R. G. E., Wood, W. A. \& Krieg, N. R. (editors) (1994). Methods for General and Molecular Bacteriology. Washington, DC: American Society for Microbiology.

Groth, I., Schumann, P., Weiss, N., Martin, K. \& Rainey, F. A. (1996). Agrococcus jenensis gen. nov., sp. nov., a new genus of actinomycetes with diaminobutyric acid in the cell wall. Int J Syst Bacteriol 46, 234-239.
Holmes, B., Owen, R. J. \& McKeekin, T. A. (1984a). Genus Flavobacterium Bergey, Harrison, Breed, Hammer and Hunton 1923, $97^{\mathrm{AL}}$. In Bergey's Manual of Systematic Bacteriology, vol. 1, pp. 353-361. Edited by N. L. Krieg \& J. G. Holt. Baltimore: Williams \& Wilkins.

Holmes, B., Owen, R. J., Steigerwalt, A. G. \& Brenner, D. J. (1984b). Flavobacterium gleum, a new species found in human clinical specimens. Int J Syst Bacteriol 34, 21-25.

Hugo, C. J., Segers, P., Hoste, B., Vancanneyt, M. \& Kersters, K. (2003). Chryseobacterium joostei sp. nov., isolated from the dairy environment. Int J Syst Evol Microbiol 53, 771-777.

Kämpfer, P., Dreyer, U., Neef, A., Dott, W. \& Busse, H.-J. (2003). Chryseobacterium defluvii sp. nov., isolated from wastewater. Int J Syst Evol Microbiol 53, 93-97.

Kim, K. K., Bae, H. S., Schumann, P. \& Lee, S. T. (2005a). Chryseobacterium daecheongense sp. nov., isolated from freshwater lake sediment. Int J Syst Evol Microbiol 55, 133-138.

Kim, K. K., Kim, M. K., Lim, J. H., Park, H. Y. \& Lee, S. T. (2005b). Transfer of Chryseobacterium meningosepticum and Chryseobacterium miricola to Elizabethkingia gen. nov. as Elizabethkingia meningoseptica comb. nov. and Elizabethkingia miricola comb. nov. Int J Syst Evol Microbiol 55, 1287-1293.

Kumar, S., Tamura, K., Jakobsen, I. B. \& Nei, M. (2001). MEGA2: molecular evolutionary genetics analysis software. Tempe, AZ: Arizona State University.

Kwon, S. W., Kim, J. S., Park, I. C., Yoon, S. H., Park, D. H., Lim, C. K. \& Go, S. J. (2003). Pseudomonas koreensis sp. nov., Pseudomonas umsongensis sp. nov. and Pseudomonas jinjuensis sp. nov., novel species from farm soils in Korea. Int J Syst Evol Microbiol 53, 21-27.

Mesbah, M., Premachandran, U. \& Whitman, W. B. (1989). Precise measurement of the $\mathrm{G}+\mathrm{C}$ content of deoxyribonucleic acid by highperformance liquid chromatography. Int J Syst Bacteriol 39, 159-167.

Mudarris, M., Austin, B., Segers, P., Vancanneyt, M., Hoste, B. \& Bernardet, J. F. (1994). Flavobacterium scophthalmum sp. nov., a pathogen of turbot (Scophthalmum maximus L.). Int J Syst Bacteriol 44, 447-453.

Sasser, M. (1990). Identification of bacteria by gas chromatography of cellular fatty acids. Technical Note no. 101. Newark, DE: MIDI Inc.

Seldin, L. \& Dubnau, D. (1985). Deoxyribonucleic acid homology among Bacillus polymyxa, Bacillus macerans, Bacillus azotofixans, and other nitrogen-fixing Bacillus strains. Int J Syst Bacteriol 35, 151-154.

Shen, F.-T., Kämpfer, P., Young, C.-C., Lai, W.-A. \& Arun, A. B. (2005). Chryseobacterium taichungense sp. nov., isolated from contaminated soil. Int J Syst Evol Microbiol 55, 1301-1304.

Vandamme, P., Bernardet, J.-F., Segers, P., Kersters, K. \& Holmes, B. (1994). New perspectives in the classification of the flavobacteria: description of Chryseobacterium gen. nov., Bergeyella gen. nov., and Empedobacter nom. rev. Int J Syst Bacteriol 44, 827-831.

Yabuuchi, E., Kaneko, T., Yano, I., Moss, C. W. \& Miyoshi, N. (1983). Sphingobacterium gen. nov., Sphingobacterium spiritivorum comb. nov., Sphingobacterium multivorum comb. nov., Sphingobacterium mizutae sp. nov., and Flavobacterium indologenes sp. nov. glucosenonfermenting gram-negative rods in CDC groups IIK-2 and IIb. Int J Syst Bacteriol 33, 580-598.

Young, C.-C., Kämpfer, P., Shen, F.-T., Lai, W.-A. \& Arun, A. B. (2005). Chryseobacterium formosense sp. nov., isolated from the rhizosphere of Lactuca sativa L. (garden lettuce). Int J Syst Evol Microbiol 55, 423-426. 